\title{
Effects of C-Reactive Protein on the Cardiac Differentiation of Mouse Embryonic Stem Cells
}

\author{
Yan Jin, Jianing Cao, Xin Xu, Xinhe Ye, Ying Chen, Jun Yang, Qiuting Feng, Liping Zhu, \\ Xi Qian, and Chengjian Yang* \\ Department of Cardiology, Nanjing Medical University Affiliated Wuxi Second Hospital; Wuxi 214002, China. \\ Received April 7, 2015; accepted June 10, 2015
}

\begin{abstract}
A major challenge in stem cell therapy for cardiac repair is how to obtain normally functioning stem cell-derived cardiomyocytes. We aim to address the effects of C-reactive protein (CRP) on the cardiac differentiation of embryonic stem (ES) cells. Immunostaining, Western blotting and electrophysiology were employed. A hundred fifty milligran/liters CRP significantly reduced the percentage of cardiomyocytes differentiated from mouse ES cells, while it may also promote sarcomere development compared to $30 \mathrm{mg} / \mathrm{L}$ CRP treatment. Further examination of the action potential (AP) in individual ES cell-derived cardiomyocytes showed that there exist three types of cardiomyocytes: artial-like (A-like), ventricular-like (V-like), and pacemaker-like (P-like). A hundred fifty milligran/liters CRP treatment decreased the P-like cardiomyocytes, whereas it increased the A-like. Such inhibitory effect and alteration were not significant at $30 \mathrm{mg} / \mathrm{L}$ CRP treatment. Moreover, $150 \mathrm{mg} / \mathrm{L}$ CRP significantly increased the APD90 (90\% of duration of AP) and decreased the spontaneous firing rate of AP in P-like cells, while had little effect on other electrophysiological characteristics, including APA (AP amplitude) and MDP (maximum diastolic potential). This study revealed the effect of CRP on the cardiac differentiation of ES cells. It provides an in vitro pathological model and may be of importance to the future work of ES cell-based therapy in clinical applications and in vivo pathological studies.
\end{abstract}

Key words cardiovascular disease; C-reactive protein; embryonic stem cell; cardiomyocyte; differentiation

Cardiac diseases are the leading cause of morbidity and mortality worldwide. Unlike some organs, the heart has pretty limited, if any, capacity for repair after injury. In particular, most adult cardiomyocytes are unable to divide and form new cardiomyocytes to replace those lost in cardiac diseases, such as in myocardial infarction, dilated cardiomyopathy, heart failure, and so forth. Traditional pharmacological management has limited efficacy and can not reverse or even prevent the progression of cardiac diseases. ${ }^{1)}$ The ultimate approach of heart transplantation is costly and it excludes patients who are poor candidates for transplantation owing to their comorbidities, or for whom a donor organ is not available.

Stem cell therapy has gained more and more popularity for cardiac repair over the years since stem cells can differentiate into cardiomyocytes, endothelial cells, and other types of cells to replace those lost in cardiac diseases after being transplanted. ${ }^{1,2)}$ Various types of stem cells have been studied in laboratory experiments and in clinical trials, including embryonic stem (ES) cells, mesenchymal stem cells (MSC), and endothelial progenitor cells (EPCs). ${ }^{1,2)}$ ES cells are pluripotent and have the potential to differentiate into tissue derivatives of all three embryonic germ layers. Numerous studies and reports demonstrated that ES cell-derived cardiomyocytes improved cardiac function significantly after being transplanted into the impaired myocardium. ${ }^{1-4)}$ MSCs, found in bone marrow, muscle, skin, and adipose tissues, can differentiate into any tissues of the mesenchymal origin. ${ }^{5)}$ Several studies indicated that MSCs differentiated into cardiomyocytes in vivo, promoted capillary formation and cardiac function. ${ }^{6-9)}$ EPCs are also derived from adult bone marrow, and can increase capillary formation by promoting vasculogenesis and angiogenesis, which in turn reduce collagen deposition and the apo- ptosis of cardiomyocytes. ${ }^{10)}$ Despite significant advances in the past years in stem cell-based therapy in animal models and in clinical trials, there are still many obstacles needed to be solved before it can be fully applied, especially, how to obtain normally functioning stem cell-derived cardiomyocytes.)

$\mathrm{C}$-Reactive protein (CRP) is an annular, pentameric protein in the blood plasma and its level increases in response to inflammation. ${ }^{11,12)} \mathrm{CRP}$ plays an important role in the initiation and progression of different types of cardiovascular diseases. ${ }^{13-15)}$ Patients with high CRP concentrations are more likely to develop atherothrombosis, stroke, myocardial infarction, and severe peripheral vascular diseases. ${ }^{16)}$ In a rat model, its overexpression exacerbated ischemic necrosis and cerebral infarcts in the complement-mediated inflammation. ${ }^{17)}$ Moreover, CRP has direct effects on stem cells. It impaired EPC antioxidant defenses, promoted EPC apoptosis, and suppressed the differentiation of EPCs into endothelial cells. ${ }^{18,19)}$ However, the effect of CRP on ES cells is yet to be further researched. In the present study, we examined the cardiac differentiation of mouse ES cells with presence of different concentrations of CRP, and we further investigated the effect of CRP on the electrophysiological properties in the ES cell-derived cardiomyocytes.

\section{MATERIALS AND METHODS}

Mouse Embryonic Stem Cell Culture Mouse embryonic fibroblasts (MEFs) were prepared from mouse embryos (13.5 D), cultured in Dulbecco's modified Eagle's medium (DMEM, Gibco, Grand Island, NY, U.S.A.) supplemented with $10 \%$ fetal bovine serum (FBS, Hyclone, Rockville, MD, U.S.A.), and passaged every $3 \mathrm{~d}$. The mouse ES cell line D3 
(purchased from ATCC) were cultured either feeder-free or on a mitomycin-C (Sigma-Aldrich, St. Louis, MO, U.S.A.) treated MEF feeder layer in DMEM supplemented with $15 \% \mathrm{FBS}$, $2 \mathrm{~mm}$ L-glutamine (Gibco), $0.1 \mathrm{~mm} \beta$-mercaptoethanol (SigmaAldrich), 1\% non-essential amino acids (NEAA, Gibco), and $1000 \mathrm{U} / \mathrm{mL}$ leukemia inhibitory factor (LIF, Chemicon, Temecula, CA, U.S.A.). Upon 80-90\% confluent, mouse ES cells were passaged with $0.25 \%$ trypsin-ethylenediaminetetraacetic acid (EDTA) (Hyclone). The cells were cultured at $37^{\circ} \mathrm{C}$ and $5 \% \mathrm{CO}_{2}$. The care and use of animals in the experiments followed the guidelines approved by the Institutional Animal Care and Use Committee (IACUC) of Nanjing Medical University Affiliated WuXi Second Hospital. The IACUC committee members at Nanjing Medical University Affiliated WuXi Second Hospital approved this study. All efforts were made to minimize the number of animals used and their suffering.

Differentiation of Mouse Embryonic Stem Cells into Cardiomyocytes Mouse ES cells were seeded into a 6-well plate $(0.1 \%$ gelatin coated) at a density of 10000 cells per well. Twenty four hours later, the culture medium was changed to conditioned medium (LG-DMEM supplemented with $10 \%$ FBS) with $10 \mu \mathrm{M}$ 5-azacytidine (5-Aza) for differentiation. After induced by 5 -Aza for $24 \mathrm{~h}$, the cells were washed with phosphate buffered saline (PBS) solution and further cultured in the conditioned medium with or without 30 or $150 \mathrm{mg} / \mathrm{L}$ CRP treatment until D20. The medium was changed every $2 \mathrm{~d}$ during experiments.

Immunofluorescence For immunofluorescence staining, after the cells were differentiated for 2 weeks post-plating (D21), cells were firstly fixed with $4 \%$ paraformaldehyde for $30 \mathrm{~min}$ at room temperature. After permeabilized with $0.1 \%$ Triton X-100 for $10 \mathrm{~min}$ and blocked with 5\% bovine serum albumin (BSA)/PBS solution for $30 \mathrm{~min}$, the cells were stained with primary antibody against Oct 4 or $\alpha$-actinin (Sigma-Aldrich), and 4'-6-diamidino-2-phenylindole (DAPI) (Sigma) in $5 \% \mathrm{BSA} / \mathrm{PBS}$ solution for $30 \mathrm{~min}$ in the dark. After 3 washes with PBS solution ( $5 \mathrm{~min}$ a time), the cells were further incubated with fluorescein isothiocyanate (FITC)-conjugated secondary antibody (Santa Cruz, TX, U.S.A.) for $30 \mathrm{~min}$ in the dark. Fluorescence images were acquired with a fluorescence microscope.

Western Blotting As a routine method, Western blotting was performed as conducted in numerous previously published literatures. Cells were collected for Western blotting at D21. The antibodies used in the study were $\alpha$-actinin (Sigma), and glyceraldehyde-3-phosphate dehydrogenase (GAPDH) (Abcam, MA, U.S.A.). Three independent experiments were conducted in the study.

Electrophysiological Recording Cells were subjected to electrophysiological recording at D21 (two weeks post-plating). Mouse ES cells were plated onto a coverslip for the recording chamber, and the action potential in cardiomyocytes were recorded with a whole-cell patch clamp equipped with an Axon 200B amplifier (Axon Instruments, NY, U.S.A.). The signal was digitized at $20 \mathrm{kHz}$, filtered at $2 \mathrm{kHz}$, and analyzed with PClamp 9.0 program. The patch pipette $(2-4 \mathrm{M} \Omega$ resistance) was filled with an solution containing $50 \mathrm{~mm}$ potassium chloride $(\mathrm{KCl}), 60 \mathrm{~mm} \mathrm{~K}$-aspartate, $1 \mathrm{~mm} \mathrm{MgCl}_{2}, 3 \mathrm{mM} \mathrm{Na}_{2} \mathrm{ATP}$, $10 \mathrm{~mm}$ ethylene glycol bis(2-aminoethyl ether)- $N, N, N^{\prime}, N^{\prime}$-tetraacetic acid (EGTA), and $10 \mathrm{~mm} N$-(2-hydroxyethyl)piperazine$N^{\prime}$-2-ethanesulfonic acid (HEPES). The $\mathrm{pH}$ was adjusted to 7.3 with potassium hydroxide $(\mathrm{KOH})$. Only the cells with spontaneous beating were included in the following observation of action potentials and subsequent analysis.

Statistical Analysis Data was expressed as mean \pm standard error of the mean (S.E.M.). Statistical analysis between groups was performed by the one-way ANOVA test followed by a Tukey test. Statistical $p$ values $<0.05$ were considered significant.

\section{RESULTS}

Embryoid Body Formation and Mouse ES Cell Identification In order to determine the effect of CRP on the cardiac differentiation, mouse ES cells were firstly cultured in suspension for $6 \mathrm{~d}$ forming embryoid bodies (EBs) before being plated into a 6 -well plate $(0.1 \%$ gelatin coated) at day 7. 5-Aza was added into the culture medium for induction at day 8 for $24 \mathrm{~h}$ before being washed out. Further, the cells were cultured and treated with $30 \mathrm{mg} / \mathrm{L}$ or $150 \mathrm{mg} / \mathrm{L} \mathrm{CRP}$ until the experiment was terminated at day 20 (Fig. 1A). The
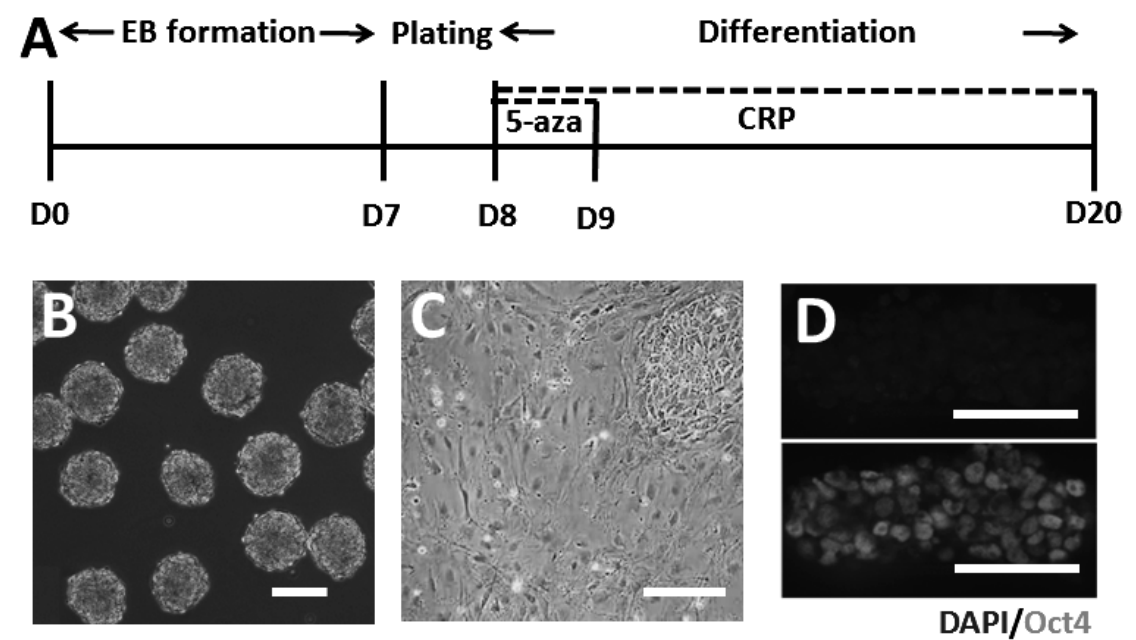

Fig. 1. Mouse Embryonic Stem Cell Cultures

(A) Experimental procedures for ES cell culturing in this study. Undifferentiated ES cells in suspension culture for $6 \mathrm{~d}$ (B) and in adherent culture after plating in day 8 (C). (D) Undifferentiated ES cells were characterized by immunostaining for their marker Oct 4 . Scale bar $=100 \mu \mathrm{m}$. 
cell condition was checked with a microscope during culture and differentiation. Undifferentiated ES cells in suspensionculture formed EBs during differentiation (Fig. 1B). After being plated, ES cells adhered to the plate surface (Fig. 1C). Immunostaining against Oct4, a specific marker of ES cells, showed that the majority of the cells were Oct4-positive (Fig. 1D), confirming that the cells used were ES cells in the study.

The Effect of CRP on the Differentiation of ES Cells into Cardiomyocytes Immunostaining was further used to study the effect of CRP on the cardiac differentiation of mouse ES cells. Immunostaining against $\alpha$-actinin showed that the mouse ES cells differentiated into cardiomyocyte, as evidenced by the appearance of $\alpha$-actinin positive cells (Fig. 2A) since $\alpha$-actinin is a marker of cardiomyocytes. Of note, sarcomeres seem to be more well developed under $150 \mathrm{mg} / \mathrm{L}$ treatment compared with the condition of $30 \mathrm{mg} / \mathrm{L}$ CRP (Fig. 2A). When the ES cells were treated with $30 \mathrm{mg} / \mathrm{L} \mathrm{CRP}$, the percentage of $\alpha$-actinin positive cells did not change, compared to that in the control (Figs. 2A, B). This observation was confirmed by Western blot analysis, in which they exhibited a similar optical density of $\alpha$-actinin after normalized with the loading control GAPDH (Fig. 2B). However, $150 \mathrm{mg} / \mathrm{L}$ CRP treatment reduced the percentage of cardiomyocyte differentiated from ES cells, as illustrated by a noticeable decrease in $\alpha$-actinin positive cells (Figs. 2A, B). Western blot analysis confirmed the inhibitory effect of $150 \mathrm{mg} / \mathrm{L} \mathrm{CRP}$ (Fig. 2C), which was consistent with previous findings. ${ }^{18,19)}$ The results were further confirmed by another marker, the antibody against sarcomeric myosin heavy chain, used to identify the cardiomyocytes differentiated from ES cells (data not shown). Together, a high level of CRP $(150 \mathrm{mg} / \mathrm{L})$, but not a moderate level $(30 \mathrm{mg} / \mathrm{L})$, reduced the number of cardiomyocytes differentiated from ES cells significantly, while may promote sarcomere development.

CRP Affected the Characteristics in the Action Potential of ES Cell Derived-Cardiomyocytes The action potential type in the differentiated cardiomyocytes was examined with a whole-cell patch clamp technique. Two weeks' differentiation after plating, most of the cells exhibited spontaneous beating, which were included for the subsequent electrophysiological recordings and statistical analysis. For those cells without automaticity, they were excluded for the following experiments.

Generally, we define the cell types on the action potentials of the cells. First, the cells did not generate action potentials were considered to be undifferentiated stem cells. Those cells which were capable of firing actions potentials were further examined by the shape and properties of action potentials to
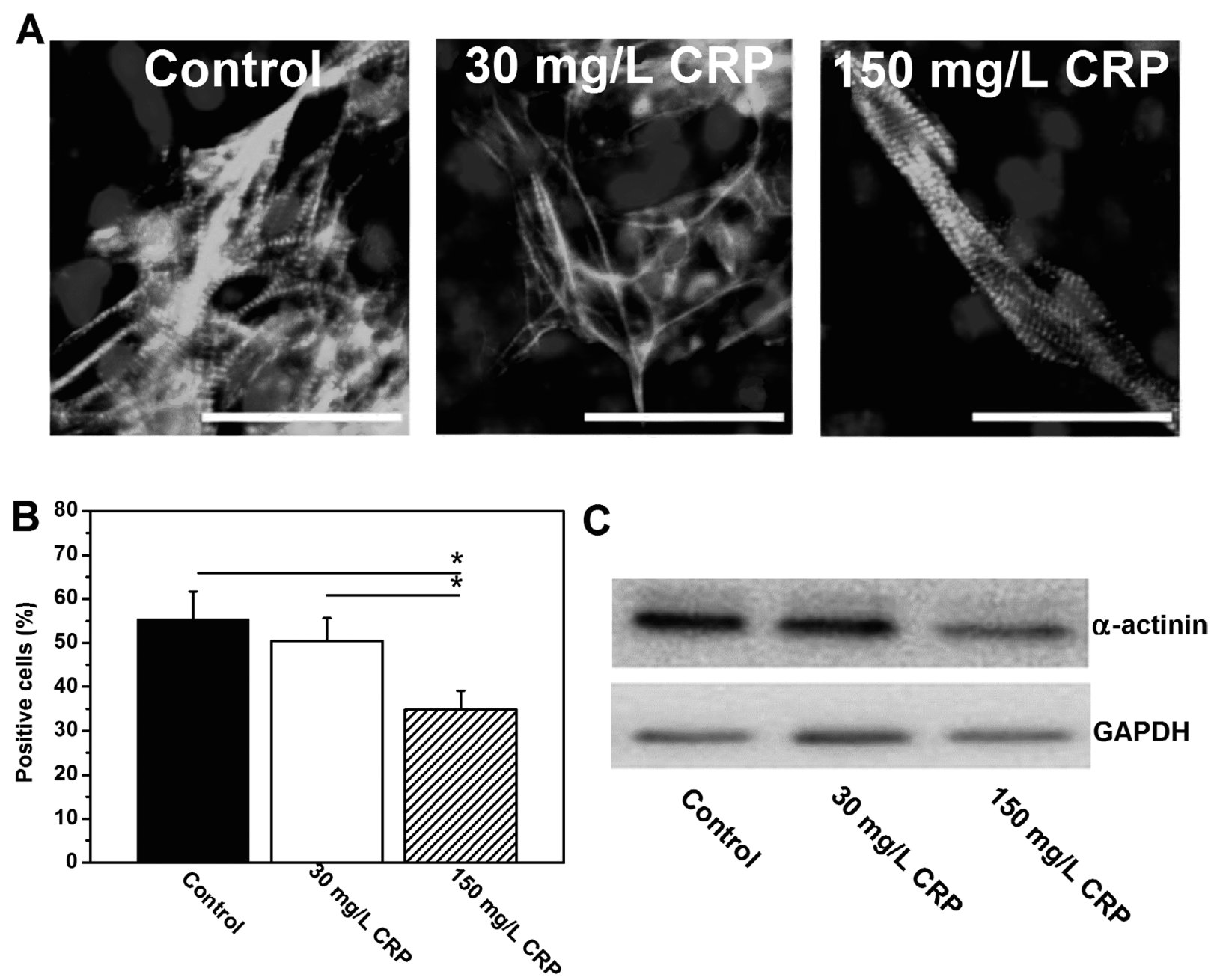

Fig. 2. Differentiation of Mouse ES Cells to Cardiomyocytes Induced by $10 \mu \mathrm{M} 5$-Aza Treatment for $24 \mathrm{~h}$

(A) The representative immunostaining images of differentiated ES cells against anti- $\alpha$-actinin and the nucleus (DAPI) in control, $30 \mathrm{mg} / \mathrm{L} \mathrm{CRP}$ and $150 \mathrm{mg} / \mathrm{L} \mathrm{CRP}$ treatment groups. (B) The percentage of anti- $\alpha$-actinin positive cell in control $(n=385), 30 \mathrm{mg} / \mathrm{L}$ CRP $(n=372)$ and $150 \mathrm{mg} / \mathrm{L}$ CRP $(n=403)$ treatment groups. $(\mathrm{C}) \mathrm{Western}$ blot analysis of the expression of $\alpha$-actinin in these three groups. Scale bar $=100 \mu \mathrm{m}$. Data were presented as mean \pm S.E.M. $* p<0.05$. 
define their types (pacemaker-like (P-like), atrial-like (A-like), ventricular-like (V-like)). We measured the maximum rate of rise of the action potential $\left(\mathrm{d} V / \mathrm{d} t_{\max }\right)$, the action potential duration (APD), action potential amplitude (APA) and phase 4 depolarization. P-like cardiomyocytes were characterized by their action potentials of prominent phase 4 depolarization, slow $\mathrm{d} V / \mathrm{d} t_{\max }$ and relatively smaller APA. For V-like and Alike cardiomyocytes, the action potentials have rapid $\mathrm{d} V / \mathrm{d} t_{\max }$ (nearly vertical shape in the rise phase of action potential). Furthermore, the action potentials of A-like cardiomyocytes usually exhibited more triangular shapes compared to those of P-like and V-like, while V-like cardiomyocytes were characterized by their action potentials of longer duration of APD and much larger APA compared to those of A-like and P-like.

The result showed that the differentiated cardiomyocytes exhibited three types of action potential: P-lik), A-like and Vlike (Fig. 3A). Further statistical analysis showed that the percentage of the three types of cardiomyocytes did not change significantly with the presence of $30 \mathrm{mg} / \mathrm{L}$ CRP, compared to that in the control (Fig. 3B). Interestingly, $150 \mathrm{mg} / \mathrm{L} \mathrm{CRP}$ treatment significantly decreased the P-like cell percentage and increased the A-like, but did not change the V-like (Fig. 3B). Together, it was demonstrated that a high dose of CRP $(150 \mathrm{mg} / \mathrm{L})$ influenced the cardiac differentiation of ES cells in terms of the action potential type in the ES cell-derived cardiomyocytes, while a low dose of CRP $(30 \mathrm{mg} / \mathrm{L})$ did not.

Electrophysiological Characteristics of P-Like, A-Like, and V-Like Cardiomyocytes after CPR Treatment The detailed electrophysiological characteristics of the three types of cardiomyocytes were further examined, including the action potential duration at $90 \%$ repolarization (APD90), APA, and the maximum diastolic potential (MDP). The values of APD90, APA, and MDP did not change significantly with the presence of $30 \mathrm{mg} / \mathrm{L}$ or $150 \mathrm{mg} / \mathrm{L}$ CRP (Fig. 4) in the three types of cardiomyocytes, except for the APD90 in P-like car- diomyocytes which increased with the presence of $150 \mathrm{mg} / \mathrm{L}$ CRP (Fig. 4A). Similar results were observed in spontaneous firing rates of the action potentials, which were significantly decreased in P-like cardiomyocytes under $150 \mathrm{mg} / \mathrm{L}$ CRP treatment (Fig. 4D).

\section{DISCUSSION}

The physiological concentration of CRP in the healthy human body is usually lower than $10 \mathrm{mg} / \mathrm{L}$, and it increases significantly under pathological situations. For instance, higher levels are found in mild inflammation $(10-40 \mathrm{mg} / \mathrm{L})$, active inflammation $(40-200 \mathrm{mg} / \mathrm{L})$, and severe bacterial infections or burns $(>200 \mathrm{mg} / \mathrm{L}) .{ }^{20}$ ) To simulate the mild and acute inflammatory concentrations in vivo, the effect of CRP on the cardiac differentiation of ES cells was investigated at $30 \mathrm{mg} / \mathrm{L}$ and $150 \mathrm{mg} / \mathrm{L}$ CRP respectively in the study. It would be of clinical significance in the treatment of human cardiac diseases with ES cell-based therapy.

In the research, the culture and induction of ES cells were well controlled. ES cells were firstly suspension-cultured forming $\mathrm{EBs}$ before being plated into a $0.1 \%$ gelatin-coated plate for adherent culture and induction with 5-Aza. The experiment demonstrated that ES cells had the ability to differentiate into cardiomyocytes properly. Worthy of mention, numerous induction protocols were reported, including optimized culture medium supplemented with different types of growth factors as well as with various compounds, such as PFT- $\alpha$, 5-Aza, Ang-II, and BMP-2. 5-Aza was used in our study, as in many other previously published literatures. ${ }^{21-24)}$ $5^{\prime}$-Aza is an inhibitor of DNA methylation, and is critical in the induction of new developmental pathways in cultured cells since cell differentiation involves stable and heritable changes, presumably of an epigenetic nature. ${ }^{24)}$ Of note, the cardiomyocytes differentiated from ES cells for $16 \mathrm{~d}$ were used for fur-
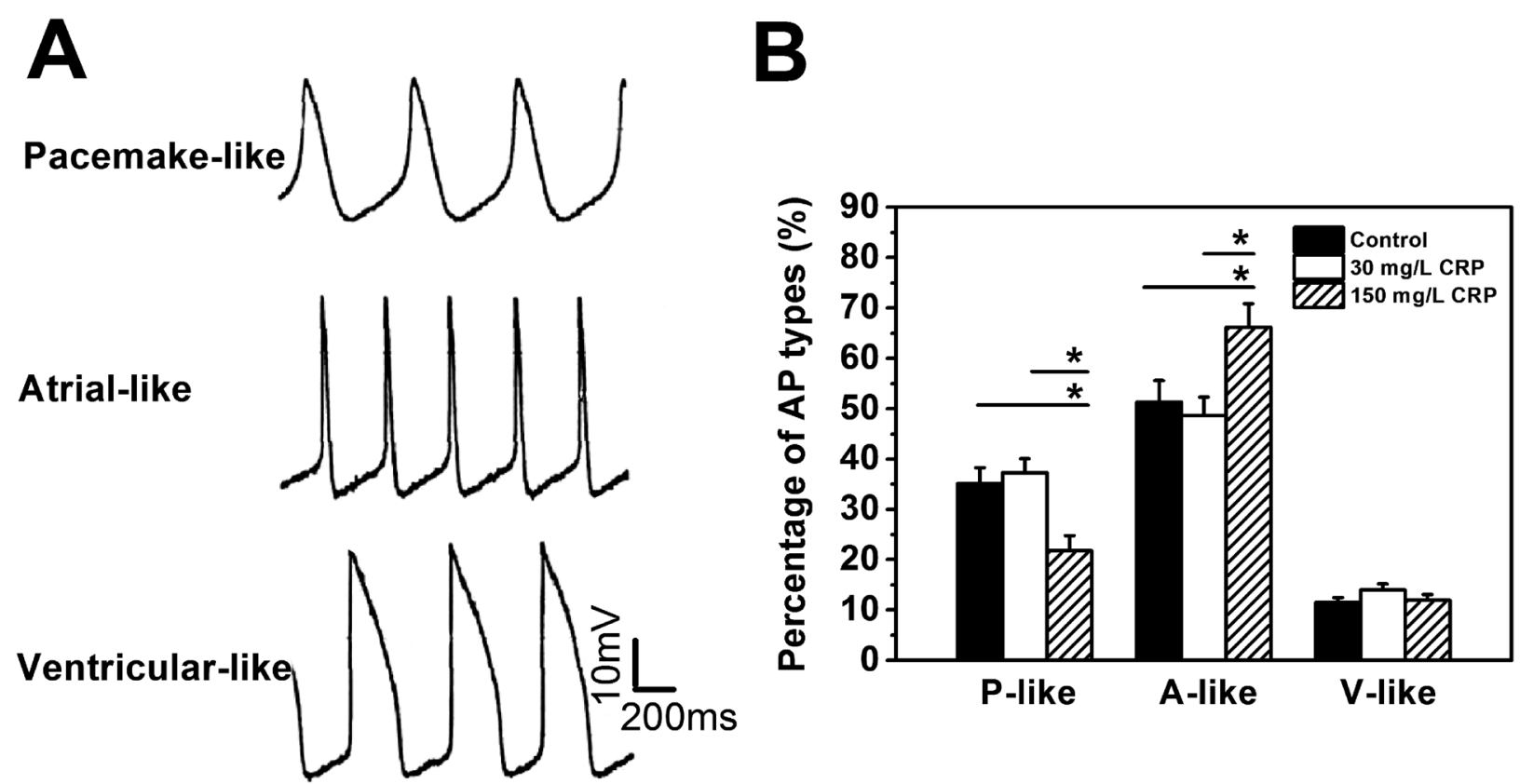

Fig. 3. Effects of CRP Treatment on ES Cells Differentiated-Cardiomyocytes with Different Characteristics in Action Potentials (APs)

(A) The typical APs for three different kinds of cardiomyocytes differentiated from ES cells for 14d, pacemaker-like cardiomyocytes (P-like), atrial-like cardiomyocytes (A-like) and ventricular-like cardiomyocytes (V-like). (B) The percentages of AP types in control, $30 \mathrm{mg} / \mathrm{L}$ CRP and $150 \mathrm{mg} / \mathrm{L}$ CRP treatment groups. Two-hundred fourtysix total cells were counted. Data were presented as mean \pm S.E.M. ${ }^{*} p<0.05$. 
A

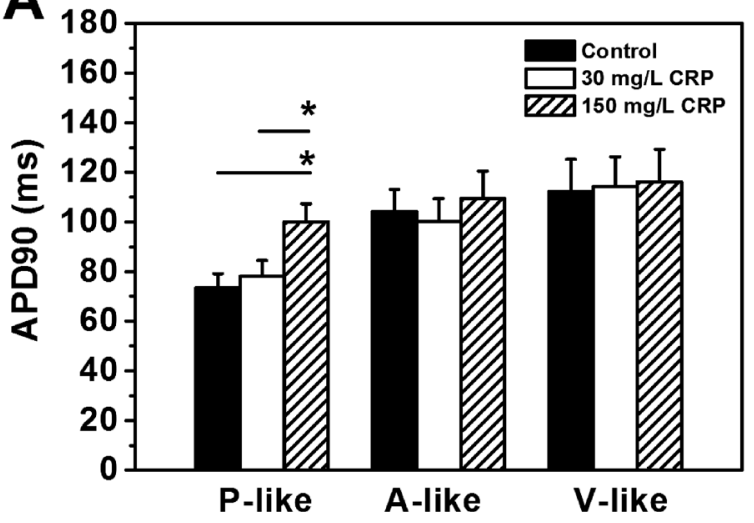

C

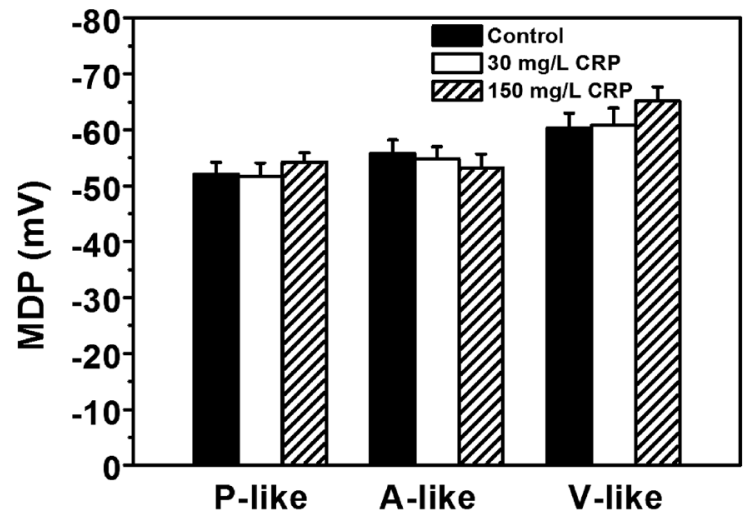

B
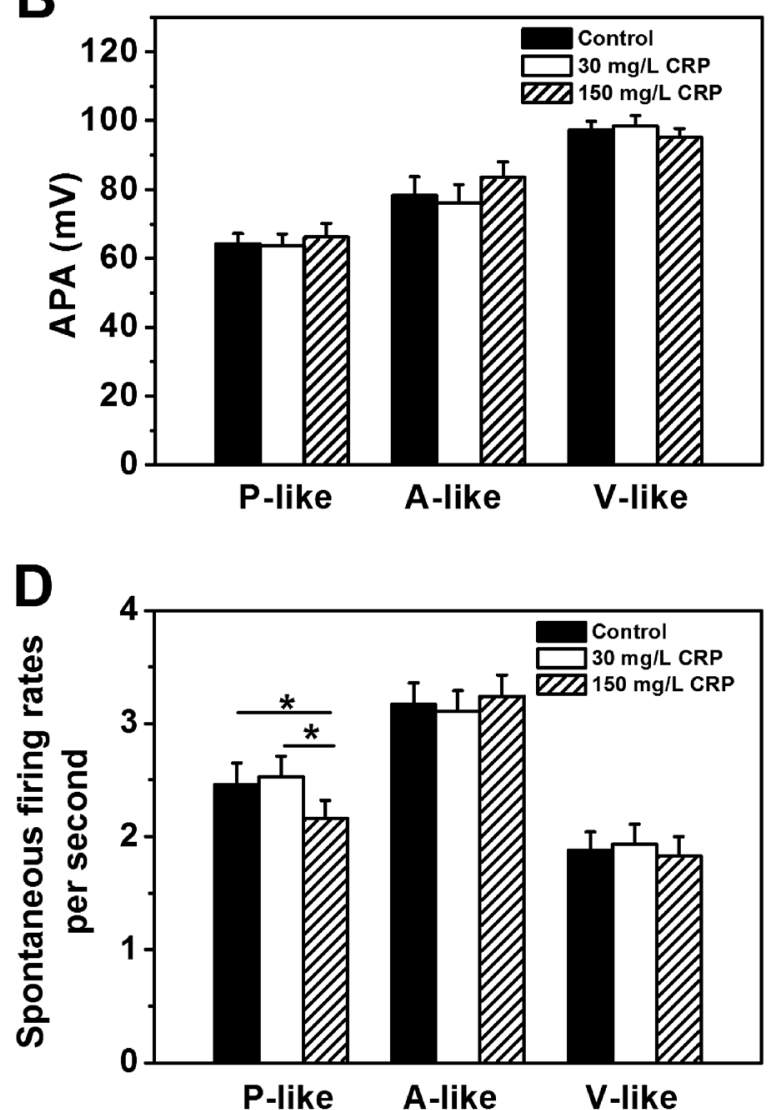

Fig. 4. Electrophysiological Characteristics of P-Like, A-Like and V-Like Cardiomyocytes Differentiated from ES Cells for $14 \mathrm{~d}$ in Control ( $n=121$ ), $30 \mathrm{mg} / \mathrm{L}(n=118) \mathrm{CRP}$ and $150 \mathrm{mg} / \mathrm{L}(n=114)$ CRP Treatment Groups, Respectively, Including 90\% of Duration of Action Potential (APD90, A), Action Potential Amplitude (APA, B), Maximum Diastolic Potential (MDP, C) and Spontaneous Firing Rates of Action Potentials (D)

Data were presented as mean \pm S.E.M. $* p<0.05$.

ther electrophysiological examinations (Figs. 3, 4) so that they were differentiated mature.

Immunostaining against the cardiomyocyte-specific protein of $\alpha$-actinin confirmed that cardiomyocytes could be derived from ES cells (Fig. 2A). In the study, it was revealed that $150 \mathrm{mg} / \mathrm{L}$ CRP reduced the percentage of cardiomyocytes differentiated from mouse ES cells. With the presence of $150 \mathrm{mg} / \mathrm{L} \mathrm{CRP}, 34 \%$ cells were cardiomyocytes, as compared to $55 \%$ in the control. However, such inhibitory effect was not significant at $30 \mathrm{mg} / \mathrm{L} \mathrm{CRP}$. However, the immunostaining result in Fig. 2A suggests $150 \mathrm{mg} / \mathrm{L}$ CRP may promote sarcomere development when compared to $30 \mathrm{mg} / \mathrm{L}$ CRP treatment. The differentiation process is very complicated and the underlying mechanisms are poorly understood. There are studies and reports demonstrating that many signaling pathways or compounds are involved in, such as STAT3, BMP, Wnt, FGF, PGC- $1 \alpha$, and reactive oxygen species. ${ }^{25-30)}$ It was not surprising that the state of the signaling pathways or compounds during differentiation might be modulated by a strong extracellular stimulus of $150 \mathrm{mg} / \mathrm{L} \mathrm{CRP}$, but not by a weaker stimulus of $30 \mathrm{mg} / \mathrm{L}$ CRP. Nevertheless, the present study demonstrated the effect of $150 \mathrm{mg} / \mathrm{L}$ CRP on the cardiac differentiation of ES cells.

Based on the type of the action potential, including resting potential, upstroke velocity, amplitude, and duration, ES cellderived cardiomyocytes are classified into three types: P-like, A-like and V-like). ${ }^{31)}$ The P-like cardiomyocytes are character- ized by a relatively depolarized resting membrane potential, while the A-like and V-like display a more stable and hyperpolarized resting potential. It was revealed that $150 \mathrm{mg} / \mathrm{L}$ CRP decreased the percentage of the P-like and increased the A-like, and did not change the V-like during differentiation. However, such alteration did not happen at $30 \mathrm{mg} / \mathrm{L}$ CRP. It suggested the differentiation of ES cells into different types of cardiomyocytes was altered by $150 \mathrm{mg} / \mathrm{L} \mathrm{CRP}$, but not by $30 \mathrm{mg} / \mathrm{L}$ CRP (mild inflammation). Also, previous studies suggest the characteristic pattern of action potential in ESdifferentiated cardiomyocytes depends on the differentiation state. $^{32)}$ A hundred milligram/liters CRP treatment decreased the percentage of P-like action potentials while increased the percentage of A-like action potentials, suggesting its capability of accelerating the ES differentiation to the terminally differentiated cardiomyocytes, which is desired for the cell therapy to treat cardiovascular diseases.

Expression levels of voltage-gated ion channels on the cell membrane, such as $\mathrm{Na}^{+}, \mathrm{Ca}^{2+}, \mathrm{K}^{+}, \mathrm{Cl}^{-}$channels, determine the electrophysiological property of a cardiomyocyte. Their expression levels in a cardiomyocyte are reflected by the action potential duration at $90 \%$ of the repolarization (APD90), APA, MDP, etc. With the presence of CRP at $30 \mathrm{mg} / \mathrm{L}$ or even $150 \mathrm{mg} / \mathrm{L}$, there was no significant change in APD90, APA, or MDP in an individual mouse ES cell-derived cardiomyocyte, compared to the control without the treatment of CRP. Of note, with the presence of $150 \mathrm{mg} / \mathrm{L} \mathrm{CRP,} \mathrm{ADP90} \mathrm{in} \mathrm{the}$ 
P-like increased. Taken together, CRP had little effect on electrophysiological characteristics of the action potential in an individual differentiated cardiomyocyte during differentiation. It might suggest that CRP had little effect on the expression of voltage-gated ion channels on the cell membrane in the differentiated cardiomyocytes even under an acute inflammatory condition (150 mg/L CRP).

Especially, stem cells therapy is usually conducted under pathological conditions, if for clinical purpose. We think the biggest advantage of using CRP is that it can mimic the pathological condition of the cardiac diseases, especially in the concentrations we chose. So, it might provide an in vitro pathological model to study the fundamental questions of cardiac differentiation. In other words, the future work, especially on clinical applications or in in vivo pathological situation, should take into account the fact that CRP may have direct effects on ES cell differentiation to the cardiomyocytes and their electrophysiological features.

\section{CONCLUSION}

To summarize, mouse ES cells differentiated into cardiomyocytes properly in the present study. A hundred fifty milligram/liters CRP reduced the percentage of cardiomyocytes differentiated from mouse ES. Meanwhile, $150 \mathrm{mg} / \mathrm{L}$ CRP increased the A-like percentage and decreased the P-like percentage in the differentiated cardiomyocytes. However, such inhibitory effect or alteration was not significant or observed at $30 \mathrm{mg} / \mathrm{L}$ CRP. Furthermore, $30 \mathrm{mg} / \mathrm{L}$ or even $150 \mathrm{mg} / \mathrm{L} \mathrm{CRP}$ did not change electrophysiological characteristics of the action potential in an individual ES cell-derived cardiomyocyte as reflected by no changes in APD90, APA, and MDP, except an increase in ADP90 decrease in spontaneous firing rate in the P-like $(150 \mathrm{mg} / \mathrm{L} \mathrm{CRP})$. In short, the present study revealed the effect of CRP on the differentiation of ES cells into cardiomyocytes with mild $(30 \mathrm{mg} / \mathrm{L} \mathrm{CRP})$ or acute $(150 \mathrm{mg} / \mathrm{L}$ CRP) inflammation. It would be of significant importance in the treatment of cardiac diseases in the human being with ES cell therapy.

Acknowledgment This work was funded by General program of Wuxi Hospital Management (Ygzxm14036).

Conflict of Interest The authors declare no conflict of interest.

\section{REFERENCES}

1) Hoover-Plow J, Gong Y. Challenges for heart disease stem cell therapy. Vasc. Health Risk Manag., 8, 99-113 (2012).

2) Abdelwahid E, Siminiak T, Guarita-Souza LC, Teixeira de Carvalho KA, Gallo P, Shim W, Condorelli G. Stem cell therapy in heart diseases: a review of selected new perspectives, practical considerations and clinical applications. Curr. Cardiol. Rev., 7, 201-212 (2011).

3) Kehat I, Gepstein A, Spira A, Itskovitz-Eldor J, Gepstein L. Highresolution electrophysiological assessment of human embryonic stem cell-derived cardiomyocytes: a novel in vitro model for the study of conduction. Circ. Res., 91, 659-661 (2002).

4) Westfall MV, Pasyk KA, Yule DI, Samuelson LC, Metzger JM. U1trastructure and cell-cell coupling of cardiac myocytes differentiating in embryonic stem cell cultures. Cell Motil. Cytoskeleton, 36,
43-54 (1997).

5) Caplan AI. Mesenchymal stem cells. J. Orthop. Res., 9, 641-650 (1991).

6) Gojo S, Gojo N, Takeda Y, Mori T, Abe H, Kyo S, Hata J, Umezawa A. In vivo cardiovasculogenesis by direct injection of isolated adult mesenchymal stem cells. Exp. Cell Res., 288, 51-59 (2003).

7) Shake JG, Gruber PJ, Baumgartner WA, Senechal G, Meyers J, Redmond JM, Pittenger MF, Martin BJ. Mesenchymal stem cell implantation in a swine myocardial infarct model: engraftment and functional effects. Ann. Thorac. Surg., 73, 1919-1925, discussion, 1926 (2002).

8) Thompson CA, Nasseri BA, Makower J, Houser S, McGarry M, Lamson T, Pomerantseva I, Chang JY, Gold HK, Vacanti JP, Oesterle SN. Percutaneous transvenous cellular cardiomyoplasty. A novel nonsurgical approach for myocardial cell transplantation. $J$. Am. Coll. Cardiol., 41, 1964-1971 (2003).

9) Toma C, Pittenger MF, Cahill KS, Byrne BJ, Kessler PD. Human mesenchymal stem cells differentiate to a cardiomyocyte phenotype in the adult murine heart. Circulation, 105, 93-98 (2002).

10) Kocher AA, Schuster MD, Szabolcs MJ, Takuma S, Burkhoff D, Wang J, Homma S, Edwards NM, Itescu S. Neovascularization of ischemic myocardium by human bone-marrow-derived angioblasts prevents cardiomyocyte apoptosis, reduces remodeling and improves cardiac function. Nat. Med., 7, 430-436 (2001).

11) Lau DC, Dhillon B, Yan H, Szmitko PE, Verma S. Adipokines: molecular links between obesity and atheroslcerosis. Am. J. Physiol., 288, H2031-H2041 (2005).

12) Pepys MB, Hirschfield GM. C-reactive protein: a critical update. $J$. Clin. Invest., 111, 1805-1812 (2003).

13) Jialal I, Devaraj S, Venugopal SK. C-reactive protein: risk marker or mediator in atherothrombosis? Hypertension, 44, 6-11 (2004).

14) Verma S, Devaraj S, Jialal I. Is C-reactive protein an innocent bystander or proatherogenic culprit? C-reactive protein promotes atherothrombosis. Circulation, 113, 2135-2150, discussion, 2150 (2006).

15) Verma S, Szmitko PE, Ridker PM. C-reactive protein comes of age. Nature Clinical Practice, 2, 29-36, quiz, 58 (2005).

16) Clearfield MB. C-reactive protein: a new risk assessment tool for cardiovascular disease. J. Am. Osteopath. Assoc., 105, 409-416 (2005).

17) Pepys MB, Hirschfield GM, Tennent GA, Gallimore JR, Kahan MC, Bellotti V, Hawkins PN, Myers RM, Smith MD, Polara A, Cobb AJ, Ley SV, Aquilina JA, Robinson CV, Sharif I, Gray GA, Sabin CA, Jenvey MC, Kolstoe SE, Thompson D, Wood SP. Targeting Creactive protein for the treatment of cardiovascular disease. Nature, 440, 1217-1221 (2006).

18) Fujii H, Li SH, Szmitko PE, Fedak PW, Verma S. C-reactive protein alters antioxidant defenses and promotes apoptosis in endothelial progenitor cells. Arterioscler. Thromb. Vasc. Biol., 26, 2476-2482 (2006).

19) Verma S, Kuliszewski MA, Li SH, Szmitko PE, Zucco L, Wang CH, Badiwala MV, Mickle DA, Weisel RD, Fedak PW, Stewart DJ, Kutryk MJ. C-Reactive protein attenuates endothelial progenitor cell survival, differentiation, and function: further evidence of a mechanistic link between C-reactive protein and cardiovascular disease. Circulation, 109, 2058-2067 (2004).

20) Clyne B, Olshaker JS. The C-reactive protein. J. Emerg. Med., 17, 1019-1025 (1999).

21) Choi SC, Yoon J, Shim WJ, Ro YM, Lim DS. 5-Azacytidine induces cardiac differentiation of P19 embryonic stem cells. Exp. Mol. Med., 36, 515-523 (2004).

22) Banerjee S, Bacanamwo M. DNA methyltransferase inhibition induces mouse embryonic stem cell differentiation into endothelial cells. Exp. Cell Res., 316, 172-180 (2010).

23) Qian Q, Qian H, Zhang X, Zhu W, Yan Y, Ye S, Peng X, Li W, $\mathrm{Xu} \mathrm{Z}$, Sun L, Xu W. 5-Azacytidine induces cardiac differentia- 
tion of human umbilical cord-derived mesenchymal stem cells by activating extracellular regulated kinase. Stem Cells Dev., 21, 67-75 (2012).

24) Boland MJ, Nazor KL, Loring JF. Epigenetic regulation of pluripotency and differentiation. Circ. Res., 115, 311-324 (2014).

25) Cai L, Ye Z, Zhou BY, Mali P, Zhou C, Cheng L. Promoting human embryonic stem cell renewal or differentiation by modulating Wnt signal and culture conditions. Cell Res., 17, 62-72 (2007).

26) Rajasingh J, Bord E, Hamada H, Lambers E, Qin G, Losordo DW, Kishore R. STAT3-dependent mouse embryonic stem cell differentiation into cardiomyocytes: analysis of molecular signaling and therapeutic efficacy of cardiomyocyte precommitted mES transplantation in a mouse model of myocardial infarction. Circ. Res., 101, 910-918 (2007)

27) Taha MF, Valojerdi MR, Mowla SJ. Effect of bone morphogenetic protein-4 (BMP-4) on cardiomyocyte differentiation from mouse embryonic stem cell. Int. J. Cardiol., 120, 92-101 (2007).

28) Wang Y, Chen G, Song T, Mao G, Bai H. Enhancement of cardiomyocyte differentiation from human embryonic stem cells. Science
China. Life Sci., 53, 581-589 (2010).

29) Birket MJ, Casini S, Kosmidis G, Elliott DA, Gerencser AA, Baartscheer A, Schumacher C, Mastroberardino PG, Elefanty AG, Stanley EG, Mummery CL. PGC-1alpha and reactive oxygen species regulate human embryonic stem cell-derived cardiomyocyte function. Stem Cell Reports, 1, 560-574 (2013).

30) Tan G, Cheng L, Chen T, Yu L, Tan Y. Foxm1 mediates LIF/Stat3dependent self-renewal in mouse embryonic stem cells and is essential for the generation of induced pluripotent stem cells. PLoS ONE, 9, e92304 (2014).

31) Hescheler J, Fleischmann BK, Lentini S, Maltsev VA, Rohwedel J, Wobus AM, Addicks K. Embryonic stem cells: a model to study structural and functional properties in cardiomyogenesis. Cardiovasc. Res., 36, 149-162 (1997).

32) Wobus AM, Rohwedel J, Maltsev V, Hescheler J. Development of cardiomyocytes expressing cardiac-specific genes, action potentials, and ionic channels during embryonic stem cell-derived cardiogenesis. Ann. N. Y. Acad. Sci., 752, 460-469 (1995). 